\title{
OS ASPECTOS INDERROGÁVEIS ACERCA DO RECONHECIMENTO DA CONDIÇÃO DE REFUGIADO E A JURISPRUDÊNCIA DOS TRIBUNAIS EUROPEUS
}

\section{THE NON-DEROGABLE ASPECTS CONCERNING THE RECOGNITION OF REFUGEE STATUS AND THE JURISPRUDENCE OF EUROPEAN COURTS}

\author{
André Ricci de Amorim*
}

\begin{abstract}
RESUMO
O objeto do presente artigo é analisar os aspectos inderrogáveis mais importantes em sede de reconhecimento da condição de refugiado e como as instituições europeias, em especial, os tribunais europeus tratam tais elementos. Deste modo, serão estudados, a partir da visão da doutrina especializada e jurisprudência dos tribunais europeus, os seguintes aspectos: o princípio do non-refoulement, a proibição de perseguição criminal e a temporariedade da concessão do asilo. Portanto, no decorrer do estudo será possível concluir que tais aspectos se tornaram verdadeiras regras imperativas que visam a proteção dos direitos humanos dessas pessoas. Assim, demonstra-se que este é um tema atual, relevante e que merece a atenção da comunidade internacional a fim de que se promovam constantes avanços no sistema de proteção aos refugiados e solicitantes de asilo no âmbito da União Europeia.
\end{abstract}

Palavras-chave: non-refoulement; proibição de perseguição criminal; temporariedade da concessão do asilo; União Europeia.

\begin{abstract}
The purpose of the present article is to examine the most important non-derogable aspects of the recognition of refugee status and how the European institutions, in particular, European courts deal with such issues. In this sense, the following aspects will be analyzed from the point of view of specialized doctrine and jurisprudence of the European courts: the principle of non-refoulement, the prohibition of criminal prosecution and the temporary nature of granting asylum. Therefore, it is possible to conclude that these aspects become mandatory rules aimed at protecting the human rights of these people. It is thus demonstrated that this is current and a relevant topic that deserves the attention of the international community in order to promote constant advances in the system of protection of refugees and asylum-seekers on the European Union.
\end{abstract}

Key-words: non-refoulement; prohibition of criminal prosecution; the temporary nature of granting asylum; European Union.

"Mestre em Ciências Jurídico-Políticas, com menção em Direito Internacional Público e Europeu pela Universidade de Coimbra, Portugal. Bacharel em Direito pela Universidade Federal do Rio de Janeiro (UFRJ). Professor substituto da Universidade Federal Fluminense (UFF). Advogado 


\section{INTRODUÇÃO}

O fenômeno das migrações humanas sempre fez parte da própria existência da humanidade. Certamente, seja qual for a motivação para o deslocamento, os refugiados e solicitantes de asilo figuram o grupo mais vulnerável.

Em meio a conflitos por motivo de raça, religião, nacionalidade, pertencimento a determinado grupo social ou político, o início da trajetória do refugiado se mostra complexa. A dificuldade em deixar sua terra natal, seu lar, sua rotina e tudo que um dia foi tão comum, agora se torna fundamental para sua sobrevivência, segurança e liberdade.

Foi justamente por essa razão que, no âmbito da Organização das Nações Unidas, foi aprovada a Convenção de Genebra relativa ao Estatuto dos Refugiados de 1951, que ainda hoje é o documento internacional mais importante em matéria de proteção dos refugiados e serviu de base, inclusive, para os instrumentos comunitários europeus (CIERCO, 2010).

Como o presente artigo trata de um assunto de interesse global, porém destacando a atuação dos tribunais europeus, necessário se faz trazer a lume a questão da nomenclatura utilizada pelas instituições europeias quando se referem à proteção desses migrantes forçados.

Ao analisar o Tratado da União Europeia, o Tratado sobre o Funcionamento da União Europeia e a Carta de Direitos Fundamentais da União Europeia (CDFUE) é possível observar que a palavra "asilo" é adotada ao invés de "refúgio".

Portanto, quando este texto se referir à proteção internacional dessas pessoas, há que se atentar para o fato de que foram utilizados como parâmetro os instrumentos jurídicos europeus que tratam do tema, cuja terminologia adotada inclina-se no sentido de chamá-lo de direito de asilo.

Todavia, ao discutir este tema no contexto latino-americano, em especial no caso brasileiro, não se pode menoscabar o fato de que asilo e refúgio guardam conceitos e procedimentos diferentes.

\footnotetext{
${ }^{1}$ UNIÃO EUROPEIA. Tratado da União Europeia. Disponível em: <http:// publications.europa.eu/resource/cellar/9e8d52e1-2c70-11e6-b497-01aa75ed71a1.0019.01/DOC_2>. Acesso em: 03 Jul. 2018 às 13h58; UNIÃO EUROPEIA. Tratado sobre o Funcionamento da União Europeia. Disponível em: <https:// eur-lex.europa.eu/legal-content/PT/TXT/?uri=celex\%3A12012E\%2FTXT>. Acesso em: Acesso em: 03 Jul. 2018 às 14h01; UNIÃO EUROPEIA. Carta de Direitos Fundamentais da União Europeia. Disponível em: $<h t t p: / / w w w$. europarl.europa.eu/charter/pdf/text_pt.pdf>. Acesso em: 03 Jul. 2018 às 14 h03.
}

O primeiro foi inspirado em alguns instrumentos jurídicos regionais, como, por exemplo, o Tratado de Direito Penal Internacional de Montevidéu, de 23 de janeiro 1889; enquanto o segundo foi consagrado mundialmente através da referida Convenção de Genebra de 1951 e o Protocolo Adicional de 1967, cujo mecanismo para a sua implementação no ordenamento jurídico pátrio é regido pela Lei 9.474, de 22 de julho de $1997^{2}$.

No contexto desse estudo, buscou-se compreender, a partir da análise da doutrina especializada e jurisprudência dos tribunais europeus, alguns pontos gerais e os aspectos inderrogáveis que incidem sobre os indivíduos que buscam reconhecer a condição de refugiado, especialmente no que tange ao princípio do non-refoulement, a proibição de perseguição criminal e a temporariedade da concessão do asilo (esse terceiro não como uma prerrogativa, mas como um aspecto geral intrínseco à concessão da proteção).

Portanto, o tema do presente trabalho é atual e de interesse geral, visto que, tem se exigido cada vez mais da comunidade internacional medidas que promovam não apenas a proteção imediata, mas soluções duradouras para essas pessoas a fim de que lhes seja dada uma nova oportunidade para gozar dos direitos e liberdades essenciais de uma vida digna.

\section{O RECONHECIMENTO DA CONDIÇÃO DE REFUGIADO}

O direito de asilo passou a ser consagrado no Direito Internacional principalmente após o fim da Segunda Guerra Mundial quando a Convenção de Genebra relativa ao Estatuto dos Refugiados de 1951 definiu, em nível global, os critérios para a sua concessão (CIERCO, 2010) $)^{3}$.

\footnotetext{
ORGANIZAÇÃO DOS ESTADOS AMERICANOS. Tratado de Direito Penal Internacional de Montevidéu. Disponível em: $<$ http://www.oas.org/es/ sla/ddi/docs/Tratado_sobre_Derecho_Penal_Internacional_Montevideo_1889. $p d f>$. Acesso em: 03 Jul. 2018 às 23h55; BRASIL. Lei 9.474, de 22 de julho de 1997. Disponível em: <http://www.planalto.gov.br/ccivil_03/Leis/L9474.htm>. Acesso em: 04 Jul. 2018 às 00h06.

${ }^{3}$ De igual forma, cumpre ressaltar que o Protocolo Adicional de 1967 Relativo ao Estatuto dos Refugiados também merece atenção da comunidade internacional, pois foi através deste que se eliminou a reserva temporal e geográfica que permitia a aplicação da Convenção de 1951 somente aos cidadãos europeus vítimas da Segunda Guerra Mundial (ALTO COMISSARIADO DAS NAÇÕES UNIDAS PARA OS REFUGIADOS. Protocolo Adicional de 1967 Relativo ao Estatuto dos Refugiados. Disponível em: $<h t t p: / / w w w . a c n u r . o r g /$ fileadmin/Documentos/portugues/BD_Legal/Instrumentos_Internacionais/ Protocolo_de_1967.pdf>. Acesso em: 03 Jul. 2018 às 18h32).
} 
Nesse sentido, importa ressaltar que o referido instrumento jurídico criou os conceitos de refugiado, as garantias concedidas aos refugiados e solicitantes de asilo, as obrigações dos Estados signatários e disposições adicionais em matéria de refúgio.

Tal Convenção foi inovadora ao trazer os critérios globais para a concessão de proteção aos indivíduos que se encontrarem em situação de risco.

Contudo, não se pode olvidar que muitos refugiados e solicitantes de asilo, na prática, ao adentrarem no território de um Estado signatário (seja ele europeu ou não europeu) encontram dificuldades em exercer o seu direito de solicitar o asilo perante as autoridades competentes. Hathaway e Foster (2014) salientam que ultimamente muitas regras domésticas e regionais têm restringido a escolha individual dos solicitantes de asilo.

Para tornar mais dinâmica e precisa a abordagem do presente trabalho, optou-se por traçar alguns pormenores acerca dos aspectos gerais e os aspectos inderrogáveis que são garantidos aos refugiados e solicitantes de asilo, independentemente do local onde o pedido é apresentado.

Assim, buscou-se analisar como os órgãos judicias europeus enxergam e concretizam a aplicação do non-refoulement, a proibição de perseguição criminal e a temporariedade da concessão do asilo.

\section{O PRINCÍPIO DO NON-REFOULEMENT}

O primeiro enfoque é o princípio do nonrefoulement, que informa não ser possível que o refugiado ou solicitante de asilo seja transferido para o seu país de origem ou de residência habitual enquanto permanecerem as circunstâncias que põem em risco sua vida, integridade física e liberdade (CIERCO, 2010).

Portanto, é possível concluir que o intuito dos Estados signatários da Convenção de Genebra de 1951 foi proteger o indivíduo de maus tratos, tortura ou penas desumanas e degradantes.

Tal princípio foi delineado pela primeira vez em 1928, no Ajuste Relativo ao Estatuto Jurídico dos Refugiados Russos e Armênios, e atualmente constitui um princípio geral do direito internacional de proteção dos refugiados e dos direitos humanos assegurado naquela Convenção, em seu Artigo 33(1) in verbis:
Nenhum dos Estados Contratantes expulsará ou rechaçará, de maneira alguma, um refugiado para as fronteiras dos territórios em que a sua vida ou a sua liberdade seja ameaçada em virtude da sua raça, da sua religião, da sua nacionalidade, do grupo social a que pertence ou das suas opiniões políticas ${ }^{4}$.

Embora passível de contestação, Stoyanova (2008) informa que o princípio do non-refoulement não pode ser garantido se não for permitido ao solicitante de asilo sequer entrar no território do Estado. Assim, a autora entende que os Estados signatários têm a obrigação de permitir que essas pessoas adentrem em seus territórios e tenham acesso aos meios necessários para solicitar o reconhecimento formal da condição de refugiado.

Ainda de acordo com Stoyanova (2008), quando isso não acontece os Estados, ao exporem o indivíduo a tamanho risco, violam os direitos humanos dos refugiados e o próprio princípio do non-refoulement.

Goodwin-Gill e McAdam (2007) ressaltam que o refoulement assume caráter próprio e não pode ser confundido com a expulsão ou deportação, processos mais formais pelos quais um estrangeiro pode deixar o Estado voluntariamente ou ser removido à força.

Por outro lado, apesar dessa repulsão ser vedada, é importante pontuar que a aplicação do non-refoulement não é ilimitada.

Tal entendimento pode ser extraído a partir da leitura do Artigo 33(2) da Convenção de Genebra de 1951, que informa não ser possível invocar o benefício quando o refugiado for considerado perigoso para a segurança do país no qual esteja ou ser condenado por crime grave com sentença transitada em julgado, passando a representar um risco para a segurança local.

Nesse sentido, o jurista Jacob Dolinger (2008) entende que somente será admitida a saída compulsória do refugiado através do instituto da expulsão, caso este traga risco para a segurança nacional ou ordem pública, garantindo, contudo, o direito do refugiado se defender e tempo suficiente para encontrar outro país que queira abrigá-10 ${ }^{5}$.

\footnotetext{
${ }^{4}$ ALTO COMISSARIADO DAS NAÇÕES UNIDAS PARA OS REFUGIADOS. Convenção Relativa ao Estatuto dos Refugiados (1951). Disponível em: $<$ http://www.acnur.org/t3/fileadmin/Documentos/portugues/BDL/Convencao_ relativa_ao_Estatuto_dos_Refugiados.pdf $>$. Acesso em: $04 \mathrm{Fev} .2018$ às $21 \mathrm{~h} 42$. ${ }^{5}$ Acerca do termo "segurança nacional" Goodwin-Gill e McAdam (2007) relembram que nem o referido termo nem o "perigo para a segurança nacional" são definidos na Convenção de Genebra de 1951, embora existam algumas exceções em legislações recentes quando relacionam, por exemplo,
} 
Neste mesmo sentido, o autor defende ainda que tal fato não ocorrerá caso o país receptor não esteja em condições de garantir sua vida ou liberdade em virtude de sua nacionalidade, religião, raça, vinculação a determinado grupo social ou opinião política.

No contexto europeu, Teresa Cierco afirma que:

As medidas adoptadas pelos Estados em defesa do seu interesse legítimo de controlo da imigração irregular, colide muitas vezes com a possibilidade dos refugiados procurarem protecção. As medidas de fiscalização fronteiriça, como o controlo nas portas de desembarque e a bordo dos aviões, juntamente com os requisitos de visto, impede o acesso dos requerentes de asilo ao procedimento de determinação do estatuto e, consequentemente, resulta no seu reenvio para situações onde sua vida e liberdade estão em perigo. Estas medidas são adoptadas em vários países da Europa Ocidental (França, Alemanha, Holanda, Noruega e Espanha). Apesar instrução administrativa incluir formalmente disposições especiais para os requerentes de asilo, na prática, estas não são, por vezes, observadas. O risco de reenvio para países de origem aumenta igualmente com as deficientes condições de interpretação e de tradução, as dificuldades de acesso a apoio jurídico e a falta de informação preliminar relativa aos procedimentos de asilo (2010, p. 78).

Não se pode deixar de mencionar que, além deste princípio ser consagrado na Convenção de Genebra de 1951, outros instrumentos jurídicos internacionais também o fizeram, tais como o Pacto Internacional sobre os Direitos Civis e Políticos, de 16 de dezembro de 1966 (PIDCP) e a Convenção das Nações Unidas contra a Tortura e Outras Penas ou Tratamentos Cruéis, de 10 de dezembro de $1984^{6}$.

\footnotetext{
a segurança nacional com o risco de terrorismo. De todo modo, os autores ressaltam que em alguns Estados, a legislação específica sobre mecanismos que visam garantir a segurança nacional e o próprio funcionamento das agências nacionais responsáveis por sua implementação podem indicar questões específicas que preocupam as autoridades estatais encarregadas de preservar a segurança. Isto pode, por sua vez, dar uma indicação dos tipos de atividades que os Estados visam coibir e permitir que se possa inferir qual é o sentido do termo "perigo para a segurança".

${ }^{6} \mathrm{O}$ PIDCP não menciona o non-refoulement de forma expressa, mas afirma ser garantido o direito à vida e veda a aplicação de tortura e outras penas ou tratamentos cruéis, desumanos ou degradantes. Nesse sentido, os Artigos $6^{\circ} \mathrm{e}$ $7^{\circ}$ merecem atenção e o texto integral se encontra disponível em: $<h t t p: / / w w w$. gddc.pt/direitos-humanos/textos-internacionais-dh/tidhuniversais/cidh-dudh-direitos-civis.html>. Acesso em: 26 Fev. 2018 às 20h09. Já a Convenção das Nações Unidas contra a Tortura e Outras Penas ou Tratamentos Cruéis (em inglês, Convention against Torture and Other Cruel, Inhuman or Degrading Treatment or Punishment) informa no Artigo $3^{\circ}$ que "nenhum Estado parte expulsará, entregará ou extraditará uma pessoa para um outro Estado quando existam motivos sérios para crer que possa ser submetida a tortura" (tradução
}

Teresa Cierco (2010, p. 79) traz à memória que o Comitê Executivo do Alto Comissariado das Nações Unidas para os Refugiados (ACNUR) concluiu que este princípio deve ser aplicado tanto internamente quanto nas fronteiras "a todos aqueles que podiam estar sujeitos a perseguição se reenviados para o seu país de origem, independentemente de terem sido ou não formalmente reconhecidos como refugiados".

Na União Europeia, cumpre salientar que o benefício do non-refoulement merece ser analisado com mais atenção, uma vez que é tratado a nível supranacional, conforme estabelecido na Diretiva 2004/83/CE.

Assim, interessa mencionar que este princípio não poderá ser derrogado quando suscitado nos moldes do Artigo $3^{\circ}$ da Convenção Europeia dos Direitos do Homem - ou simplesmente CEDH (COSTELLO, 2016) $)^{7}$.

O caso Saadi vs. Itália abordou bem a questão quando o Tribunal Europeu dos Direitos Humanos (TEDH) foi acionado para se manifestar acerca da interpretação do referido dispositivo jurídico sobre a obrigação de não repulsão de solicitantes de asilo na União Europeia ${ }^{8}$.

Nassim Saadi, cidadão tunisiano e residente em Milão acionou o TEDH em razão de sua eventual expulsão para a Tunísia, local onde alega ter sido condenado em 2005 a 20 anos de prisão mesmo diante de sua ausência por, de acordo com as autoridades tunisianas, fazer parte de uma organização terrorista que atua no exterior, bem como por promover a incitação ao terrorismo. Ao saber disso, Saadi solicitou asilo perante as autoridades italianas que posteriormente negaram provimento?.

Além da denegatória, o Ministro da Administração Interna italiano (em italiano, Ministro dell'Interno) determinou sua deportação suscitando a lei italiana de combate ao terrorismo e motivando o ato com base no processo instaurado na Tunísia, no

livre). O texto integral se encontra disponível em: <http://www.ohchr.org/EN/ Professionalinterest/Pages/CAT.aspx>. Acesso em: 26 Fev. 2018 às 20 h09. ${ }^{7}$ Assim, o Artigo $3^{\circ}$ da Convenção Europeia dos Direitos do Homem traz a seguinte redação: "Ninguém pode ser submetido a torturas, nem a penas ou tratamentos desumanos ou degradantes” (UNIÃO EUROPEIA. Convenção Europeia dos Direitos do Homem. Disponível em: <http://www.echr.coe.int/ Documents/Convention_POR.pdf>. Acesso em: 14 Mar. 2018 às 21h13).

${ }^{8}$ Referente ao caso Saadi vs. Itália (37201/06) julgado pelo Tribunal Europeu de Direitos Humanos em 28 de fevereiro de 2008. Disponível em: <http:// hudoc.echr.coe.int/eng\#\{“dmdocnumber":[“829510"],"itemid”:[“001-85276”]\}>. Acesso em: 14 Mar. 2018 às $21 \mathrm{~h} 15$.

${ }^{9}$ Idem. 
qual demonstrava que o requerente tinha um papel ativo numa organização terrorista ${ }^{10}$.

Logo, as autoridades italianas entenderam ser possível a retirada compulsória de Saadi, pois havia garantia da Tunísia de que o Artigo $3^{\circ}$ da CEDH seria assegurado $^{11}$.

Vale ressaltar que esse dispositivo já havia sido anteriormente interpretado pelo TEDH no sentido de proibir o regresso ou a extradição de indivíduos para Estados nos quais se deparasse um risco real de tortura, tratamento desumano ou degradante.

No caso em questão, o TEDH entendeu que embora as autoridades tunisianas informassem que não haveria a aplicação de penas degradantes ao solicitante de asilo, o Tribunal considerou que a mera existência de proibições internas de tortura e maus-tratos não era suficiente para garantir a proteção adequada dos direitos de Saadi conforme o Artigo $3^{\circ}$ da CEDH, uma vez que fontes fidedignas declararam que as práticas, apesar de formalmente proibidas, eram praticadas ou toleradas pelo Estado receptor.

Portanto, esse caso serviu para que o TEDH reafirmasse unanimemente a jurisprudência existente acerca do non-refoulement já que se entendeu haver um risco de submeter o solicitante a tratamento degradante caso fosse deportado.

Ademais, o Tribunal salientou que a participação no terrorismo não afeta os direitos absolutos de um indivíduo nos termos do Artigo $3^{\circ}$ da CEDH.

Embora não tenha relação direta (ou semelhante) com o caso, porém em congruência com esse entendimento, Costello (2016) informa que os diversos casos julgados pelo TEDH contribuíram para a proteção dos refugiados na Europa, pois dentre outras explicações, esclareceu que a obrigação de não afastamento pode surgir independentemente da ameaça ser perpetrada por agentes estatais ou privados.

Por fim, vale ressaltar que a Comissão Europeia vem reforçando a ideia entre os Estados-Membros de que suas legislações internas devem respeitar o princípio do non-refoulement. Ocorre que a grande dificuldade tem sido em relação ao tratamento dos indivíduos que entram de forma irregular em território da União.

Ora, se por um lado não existe qualquer instrumento no âmbito europeu que impeça os Estados de criminalizarem a entrada irregular, por outro não parece

${ }^{10}$ Idem.

${ }^{11}$ Idem. justo punir alguém que ao ser perseguido deixa sua pátria e entra irregularmente num determinado território buscando simplesmente a manutenção de sua vida.

Nesse sentido, importa trazer à baila também o Artigo 19 da Carta de Direitos Fundamentais da União Europeia (CDFUE) que informa o seguinte: "ninguém pode ser afastado, expulso ou extraditado para um Estado onde corra sério risco de ser sujeito a pena de morte, a tortura ou a outros tratos ou penas desumanos ou degradantes" 12 .

Portanto, nota-se que o non-refoulement é formalmente reconhecido como regra imperativa, servindo de proteção aos refugiados e solicitantes de asilo que buscam proteção na União Europeia.

\section{A PROIBIÇÃO DE PERSEGUIÇÃO CRIMINAL}

De fato, não é possível negar que os Estados são soberanos para promover a detenção de nacionais e estrangeiros que infrijam suas regras internas ${ }^{13}$. Contudo, o exercício desse poder deve ser analisado com atenção em matéria de proteção aos refugiados e solicitantes de asilo.

Nesse sentido, a segunda inovação trazida pela Convenção de Genebra de 1951 foi a proibição de perseguição criminal ao indivíduo que ingresse ou se encontre em situação migratória irregular no Estado onde apresenta a solicitação de asilo. O Artigo 31(1) da Convenção diz que:

Os Estados Contratantes não aplicarão sanções penais em virtude da sua entrada ou permanência irregulares, aos refugiados que, chegando diretamente do território no qual sua vida ou sua liberdade estava ameaçada no sentido previsto pelo art. $1^{\circ}$, cheguem ou se encontrem no seu território sem autorização, contanto que se apresentem sem demora às autoridades e lhes exponham razões aceitáveis para a sua entrada ou presença irregulares ${ }^{14}$.

\footnotetext{
${ }^{12}$ UNIÃO EUROPEIA. Carta de Direitos Fundamentais da União Europeia. Disponível em: <http://www.europarl.europa.eu/charter/pdf/text_pt.pdf>. Acesso em: 03 Jul. 2018 às 20h47.

${ }^{13}$ Tal assertiva se fundamenta na Teoria da Constituição dos Estados, que informa que a concepção jurídica de Estado se pauta em três elementos, a saber: o povo, o território e o poder político não subordinado a qualquer autoridade estrangeira (BRITO, 2014). Portanto, a partir do momento em que um Estado se constitui para a ciência jurídica, é possível concluir que a criação das leis é papel privativo do Estado, visto que a soberania é uma característica fundamental que permite o exercício de suas atividades sem qualquer ingerência orgânica interna ou externa (MACHADO, 2013).

${ }^{14}$ ALTO COMISSARIADO DAS NAÇÕES UNIDAS PARA OS REFUGIADOS.
} 
Tal garantia se justifica para evitar a criminalização dos refugiados que, ao deixarem o seu local de origem, geralmente não conseguem cumprir os trâmites administrativos para entrar noutro Estado de forma regular (solicitação de passaporte, visto de entrada, etc.). Assim, não é incomum que essas pessoas estejam sem qualquer documento de identificação ou portem documentos falsos quando abordados nas fronteiras.

Portanto, o que se faz neste caso é mitigar a conduta do refugiado e a consequência para o seu ato, porém sem estabelecer uma punição que crie obstáculos ou impeça que o pedido de asilo seja analisado. Deve-se observar que geralmente o refugiado não tem muito tempo para planejar a sua fuga e esta conduta foi uma medida desesperada de preservar sua vida.

Acerca dessa questão, Hathaway (1991) salienta que a Convenção de Genebra de 1951 não estabelece a entrada regular do indivíduo como requisito para a análise do pedido de reconhecimento da condição de refugiado.

No entanto, a condição para que não haja essa sanção aos solicitantes de asilo pode gerar dúvida justamente por não trazer claramente o conceito de "sem demora às autoridades" e "razões aceitáveis para a sua entrada ou presença irregulares".

A doutrina especializada no estudo do tema entende que não se pode interpretar essa parte do Artigo 31(1) de forma absoluta e restritiva. Hathaway (1991) entende que a não apresentação imediata pode ocorrer por diversos fatores, tais como o desconhecimento do solicitante e/ou o medo de sofrer algum tipo de perseguição dos agentes do Estado. Deste modo, trata-se de uma questão que dependerá da casuística.

De fato, a interpretação do Artigo 31(1) da Convenção demanda atenção, pois se por um lado os Estados não podem simplesmente derrogá-lo, por outro há quem defenda a adoção de medidas rígidas para desencorajar a migração irregular.

Nesse sentido, é importante ressaltar que esse benefício é restrito ao refugiado que busca proteção internacional, não podendo ser suscitado pelos migrantes econômicos e ambientais, por exemplo.

Diferentemente da teoria, tem-se observado que diante do grande fluxo migratório recente na União Europeia, muitos refugiados que chegam em situação

Convenção Relativa ao Estatuto dos Refugiados (1951). Disponível em: $<$ http://www.acnur.org/t3/fileadmin/Documentos/portugues/BDL/Convencao relativa_ao_Estatuto_dos_Refugiados.pdf $>$. Acesso em: 02 Mar. 2018 às $20 \mathrm{~h} 49$. irregular não recebem o tratamento de acordo com a Convenção de Genebra e, ao cruzarem as fronteiras, são detidos e mantidos em campos de contentores (VIANA, 2017).

Goodwin-Gill e McAdam (2007) reforçam que em caso de aumento do fluxo migratório, ainda assim, o princípio contido no artigo 31 da Convenção de Genebra de 1951 continuará a ser aplicado, embora, na prática, alguns Estados tendam a criar campos contentores como solução interina enquanto decidem se procedem na repatriação ou no reassentamento em terceiro país.

Adentrando ao conteúdo, Costello (2016) ressalta que a despeito de parte da doutrina considerar que apenas as sanções penais são excluídas, outra parte significativa dos especialistas em migrações considera que pelo menos algumas formas de detenção devem ser igualmente proibidas como forma de punição.

O caso Qurbani vs. Alemanha, julgado pelo Tribunal de Justiça da União Europeia (TJUE) ilustra o quão difícil pode ser a interpretação do referido dispositivo.

Nesse episódio, o solicitante de asilo entrou e permaneceu em território alemão de forma irregular portando um passaporte falsificado e ao ser flagrado em tal prática solicitou o reconhecimento da condição de refugiado.

Assim, as autoridades alemãs levaram o caso ao tribunal local intentando promover a punição do solicitante pela prática citada.

O Tribunal de Bamberg, em sede de reenvio prejudicial, questionou o TJUE se: 1) a isenção de sanções prevista no artigo 31 da Convenção de Genebra de 1951 inclui também, além da sua redação, a falsificação de documentos mesmo que este documento não seja necessário para dar entrada na solicitação de asilo (no caso, um passaporte falsificado apresentado a um policial quando da entrada por via aérea na Alemanha)? 2) O uso de contrabandistas de pessoas exclui o recurso ao referido artigo? 3) O referido benefício poderia ser suscitado mesmo quando o interessado não tenha vindo diretamente do país que sofreu perseguição, uma vez que o interessado entrou em primeiramente por outro Estado-Membro (Grécia) de onde seguiu para outro Estado-Membro onde pede asilo (Alemanha)?

Assim, os questionamentos referente a interpretação do Artigo 31 não puderam ser solucionados nesse caso, pois o TJUE declarou que por se tratar de 
uma interpretação única e exclusiva de dispositivo da Convenção de Genebra de 1951, este órgão não possui jurisdição para proceder nesse sentido ${ }^{15}$.

Contudo, se existe a dificuldade em delimitar as circunstâncias que justificam o Artigo 31, não se pode deixar de mencionar que o ACNUR (2001) já se manifestou no sentido de que a detenção deve ser a ultima ratio, sendo justificável apenas nas hipóteses de:

a) verificação de identidade quando esta for indeterminável;

b) enquanto não se realizar a entrevista preliminar para obter fatos essenciais que baseiam o pedido de asilo. Porém, o ACNUR esclarece que isso não significa detenção para todo o procedimento de determinação de status, ou por um período ilimitado de tempo;

c) Nos casos em que os requerentes de asilo tenham destruído seus documentos de identidade ou viagem ou tenham usado documentos fraudulentos a fim de induzir ao erro a autoridade competente do país em que pretendem requerer asilo. Nesse caso, as autoridades devem demonstrar que o requerente de asilo atuou de má-fé e tinha a intenção de induzir ao erro ou se recusou a cooperar com as autoridades do país acolhedor. Em todo caso, o órgão informa que os solicitantes de asilo que chegam sem documentos por razões alheias à sua vontade não devem ser detidos apenas por esse motivo; e

d) solicitantes que oferecem risco à segurança nacional e ordem pública. Nesse caso, as autoridades precisam demonstrar que o indivíduo possui antecedentes criminais e/ou afiliações que possam constituir um risco para a segurança nacional ou para a ordem pública. Contudo, os solicitantes de asilo que chegarem como parte de um esquema de tráfico ou contrabando normalmente não serão incluídos nesta categoria e não deverão ser detidos apenas por esse motivo, pois geralmente são vítimas de atividades criminosas, não criminosos ${ }^{16}$.

Seguindo essa lógica de proteção presente tanto na Convenção de Genebra de 1951 quanto nos diversos instrumentos jurídicos europeus em matéria

\footnotetext{
${ }^{15}$ Referente ao caso Qurbani vs. Alemanha (Processo C-481/13). Disponível em: <http://curia.europa.eu/juris/document/document.jsf?text $=\&$ docid $=15$

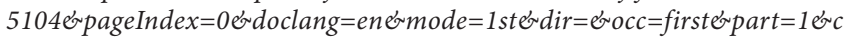
$i d=321873>$. Acesso em: 26 Mar. 2018 às $23 \mathrm{~h} 12$.

${ }^{16}$ Especificamente sobre o item (d) acima, Goodwin-Gill e McAdam (2007, pp. 183-184) afirmam: "whether a refugee is a danger to security or a danger to the community, or has committed a 'serious non-political crime', can only be determined on the basis of the evidence relating to that individual".
}

de asilo, o Tribunal de Justiça da União Europeia já tem restringido que alguns Estados-Membros mantenham presos indivíduos que entraram em seu território de forma irregular para solicitar asilo (vide Caso C-329/11 - Alexandre Achughbabian vs. Préfet du ValdeMarne).

\section{A TEMPORARIEDADE DA CONCESSÃO DO ASILO}

O terceiro aspecto que merece destaque é a temporariedade da concessão do asilo. Isso quer dizer que, mesmo obtendo o reconhecimento da condição de refugiado, tal situação é temporária e aplicável enquanto durarem as razões que causaram a fuga do território. O ideal, no caso dos refugiados, é a repatriação voluntária, ou seja, o retorno dessas pessoas aos seus países de origem ou de residência habitual a partir do momento em que a situação voltar à normalidade, já que após o fim da perseguição o asilo não mais se justifica (GILBERT, 1998).

Assim, tem-se observado que o ACNUR se esforça para assegurar não apenas a proteção imediata, mas também para garantir soluções duradouras de proteção, das quais se destacam: $(i)$ a repatriação voluntária, quando os indivíduos retornam ao seu lar por livre e espontânea vontade após o encerramento das razões que deram causa ao refúgio, sendo primordial que o país assegure que os direitos dessas pessoas não mais serão violados; (ii) a integração local, método de adaptação aos costumes locais a partir da inclusão do refugiado no contexto social, cultural e econômico do país que o acolhe; e (iii) o reassentamento, quando o refugiado já é reconhecido pelo ACNUR ou pelo país de primeira acolhida, mas por não poder permanecer neste ou nele não se adaptar, precisa seguir para um terceiro país a fim de garantir sua integridade física e moral.

Hathaway e Foster (2014) ressaltam que, além da repatriação voluntária e o retorno da normalidade ao país de origem do refugiado, a cessação do asilo também pode ocorrer: $a$ ) pela reaquisição voluntária da nacionalidade, conforme artigo 1(C)(2) da Convenção de Genebra de 1951 que afirma que a Convenção deixará de ser aplicada na hipótese do refugiado "havendo perdido a nacionalidade, ela a 
recuperou voluntariamente"; $b$ ) mudança de circunstâncias; e c) aquisição de nova nacionalidade ${ }^{17}$.

No que tange a temporariedade da concessão do asilo e analisando-a sob uma perspectiva concreta, o caso Abdulla e outros vs. Alemanha demonstra como pode ocorrer a cessação do status de refugiado ${ }^{18}$.

Nesse caso, os solicitantes eram refugiados de nacionalidade iraquiana reconhecidos desde $2001 \mathrm{e}$ 2002, cuja concessão se deu em razão da perseguição perpetrada pelo regime do Partido Ba'ath de Saddam Hussain. Ocorre que, a partir de 2004, devido às mudanças ocorridas no cenário político iraquiano, o Governo Alemão iniciou procedimentos para revogar o reconhecimento da condição de refugiado dos solicitantes.

$\mathrm{Na}$ Alemanha, quando o processo foi recebido pelo órgão jurisdicional de última instância administrativa (em alemão, Bundesverwaltungsgericht), foi decidido que não havia razão para impedir a revogação do reconhecimento da condição de refugiado uma vez que os recorrentes no processo principal estavam a salvo da perseguição sofrida pelo regime anterior e que não estavam mais sujeitos a qualquer ameaça de perseguição por qualquer outro motivo.

Apesar dos solicitantes terem interposto recurso administrativo, a decisão foi mantida. Contudo, é interessante notar que mesmo assim o Bundesverwaltungsgericht suspendeu o processo e enviou a questão para o TJUE em sede de reenvio prejudicial.

Nesse sentido, o órgão alemão submeteu questões pormenorizadas ao TJUE para solucionar o caso de acordo com as normas da União Europeia.

A primeira questão buscava saber se a cessação deveria ter lugar após a cessação das razões subjacentes ao reconhecimento da condição de refugiado de refugiado, ou seja, se havia simetria entre o motivo da concessão e a cessação do status de refugiado. Se a resposta a esta questão fosse negativa, a questão seguinte buscava solucionar quais os outros fatores

\footnotetext{
${ }^{17}$ Quanto à reaquisição de nacionalidade dos refugiados os autores ressaltam o seguinte: "this cessation clause does not apply to stateless persons who secure the citizenship of their country of former habitual residence, assuming they were not previously nationals of that country. And because it is Art. 1 (C)(3) that addresses the question of loss of status upon acquisition of a 'new nationality', Art. $1(C)(2)$ interpreted in the context addresses only the acquisition of the nationality of the country in relation to which refugee status was established" (HATHAWAY; FOSTER, 2014, p. 471).

${ }^{18}$ Referente ao caso Abdulla e outros vs. Alemanha (Processos C-175/08, C-176/08, C-178/08 e C-179/08). Disponível em: <http://eur-lex.europa.eu/ legal-content/EN/TXT/?uri=CELEX\%3A62008CJ0175>. Acesso em: 15 Mar. 2018 às $20 \mathrm{~h} 54$.
}

que deveriam ser avaliados e quais as normas que deveriam ser consideradas (COSTELLO, 2016).

Portanto, o TJUE afirmou que o Artigo 11(e) da Diretiva 2004/83/EC deveria ser interpretado de forma que: a) o status de refugiado deixa de existir quando as circunstâncias que justificaram o temor de perseguição por uma das razões elencadas no Artigo $2^{\circ}$ (c) da Diretiva 2004/83/EC deixarem de existir em função de uma mudança das circunstâncias em carácter significativo e não temporário no país terceiro em causa; b) para efeitos de avaliação de uma alteração das circunstâncias, as autoridades competentes do Estado-Membro devem considerar a situação individual do refugiado ao mesmo tempo em que verifica que os agentes de proteção referidos no Artigo $7^{\circ}(1)$ da Diretiva 2004/83 tomaram medidas razoáveis para impedir a perseguição, bem como promoveram medidas jurídicas para detecção, repressão e punição de atos que constituam perseguição e, por fim, que o nacional em causa terá acesso a essa proteção quando cessar o status de refugiado; c) os agentes de proteção referidos no artigo $7^{\circ}(1)$ (b) da Diretiva 2004/83/EC podem incluir organizações internacionais que controlem o Estado ou uma parte substancial do território do Estado, incluindo força multinacional presente nesse Estado; d) quando as circunstâncias que deram causa à concessão do asilo deixaram de existir e as autoridades competentes do Estado-Membro verificam que não existem outras circunstâncias que justifiquem a sua manutenção, o critério de probabilidade utilizado para avaliar o risco decorrente dessas outras circunstâncias é o mesmo que o aplicado no momento da concessão do asilo; e, por fim, e) o Artigo $4^{\circ}(4)$ da Diretiva 2004/83/EC pode aplicar-se quando as autoridades competentes pretendem retirar o status de refugiado nos termos do Artigo 11(1)(e) da mesma Diretiva e o interessado, a fim de demonstrar a existência de um fundado temor de perseguição, baseia-se em circunstâncias diversas das que resultaram o seu reconhecimento como refugiado. Contudo, isso geralmente seria admissível nos casos em que a razão da perseguição mesmo sendo diferente daquela aceita no momento em que o solicitante foi reconhecido como refugiado, mantenha alguma relação anterior com os motivos da perseguição.

De todo modo, ao analisar a jurisprudência, observa-se que ultimamente os Estados raramente utilizam o recurso da cessação da proteção, especialmente se o reconhecimento da condição de refugiado 
com o tempo desencadeou na concessão da residência permanente ou por tempo indeterminado.

Dessa forma, o que ocorre é que a disposição sobre a cessação é frequentemente incluída na legislação de âmbito local como acontece, por exemplo, na Suíça e no Canadá (GOODWIN-GILL; MCADAM, 2007).

\section{CONSIDERAÇÕES FINAIS}

A luta dos refugiados, mais que uma luta por um viver digno, é constante e motivada por um único fator, qual seja, a manutenção da própria vida. Ao analisar os jornais, percebe-se que os tempos atuais são muito difíceis: mais de 65 milhões de vítimas de deslocamentos forçados ao redor do mundo, número recorde desde a Segunda Guerra Mundial (ALTO COMISSARIADO DAS NAÇÕES UNIDAS PARA OS REFUGIADOS, 2016).

Nesse sentido, o presente estudo teve por objetivo evidenciar, com base na jurisprudência dos tribunais europeus e os principais documentos internacionais e comunitários em matéria de asilo, alguns aspectos gerais e os aspectos inderrogáveis do reconhecimento da condição de refugiado.

Ora, da mesma forma que os Estados utilizam-se de critérios objetivos elencados no $\operatorname{artigo~} 1^{\circ}(2)$ da Convenção de Genebra de 1951 para garantir a proteção aos refugiados, mister se faz que eles também reconheçam que existem certas prerrogativas ao tratar do tema, das quais foram destaque neste trabalho: o princípio do non-refoulement, a proibição de perseguição criminal e a temporariedade da concessão do asilo (reitera-se que esse último não deve ser tratado como uma prerrogativa, mas como um aspecto geral intrínseco à concessão do asilo) $)^{19}$.

No que tange às garantias é fundamental que elas sejam observadas pela comunidade internacional para a efetiva proteção dos direitos humanos dos refugiados, uma vez que essas pessoas se encontram em vulnerabilidade e não podem contar com o

\footnotetext{
${ }^{19}$ Nos termos de seu Artigo $1^{\circ}(2)$, o termo "refugiado" se aplicará a qualquer pessoa: “(...) temendo ser perseguida por motivos de raça, religião, nacionalidade, grupo social ou opinióes políticas, se encontra fora do país de sua nacionalidade e que não pode ou, em virtude desse temor, não quer valer-se da proteção desse país, ou que, se não tem nacionalidade e se encontra fora do país no qual tinha sua residência habitual em consequência de tais acontecimentos, não pode ou, devido ao referido temor, não quer voltar a ele" (ALTO COMISSARIADO DAS NAÇÕES UNIDAS PARA OS REFUGIADOS. Convenção Relativa ao Estatuto dos Refugiados (1951). Disponível em: <http://www.acnur.org/t3/ fileadmin/Documentos/portugues/BDL/Convencao_relativa_ao_Estatuto_dos_ Refugiados.pdf>. Acesso em: Acesso em: 04 Fev. 2018 às 21h42).
}

resguardo do Estado com o qual possuem vínculo de nacionalidade.

De todo modo, não há dúvidas de que essa realidade global onde o número de refugiados só aumenta, traz um verdadeiro desafio aos Estados acolhedores, qual seja, o de manter o compromisso de proteção aos refugiados sem que isso estimule um fluxo migratório desordenado que agrave os problemas socioeconômicos porventura já existentes em seu território.

Portanto, o que se pode notar é que as dificuldades em enfrentar a (popularmente) chamada "crise dos refugiados" têm mais relação com a resistência política e ideológica do que com os recursos e instrumentos jurídicos ${ }^{20}$.

Por fim, acredita-se que a verdadeira garantia dos direitos humanos ocorre quando todos os indivíduos, sejam nacionais ou estrangeiros, têm acesso aos bens imateriais necessários para se viver dignamente, como educação, saúde, habitação, alimentação e acesso ao mercado de trabalho.

\section{REFERÊNCIAS}

ALTO COMISSARIADO DAS NAÇÕES UNIDAS PARA OS REFUGIADOS. Convenção Relativa ao Estatuto dos Refugiados (1951). Disponível em: <http://www.acnur. org/t3/fileadmin/Documentos/portugues/BDL/Convencao relativa_ao_Estatuto_dos_Refugiados.pdf $>$. Acesso em: $0 \overline{4}$ Fev. 2018 às $21 \mathrm{~h} 42$.

Global Trends: Forced Displacement in 2016. Genebra: United Nations High Commissioner for Refugees, 2017. Disponível em: <http://www.unhcr.org/5943e8a34. $p d f$ >. Acesso em: 09 Abr. 2018 às 18h03.

Mid-Year Trends 2017. Genebra: United Nations High Commissioner for Refugees, 2017. Disponível em: $<$ http://www.unhcr.org/statistics/unhcrstats/5aaa4fd27/mid-

\footnotetext{
${ }^{20}$ Cumpre ressaltar que o autor acredita que o uso da expressão "crise de refugiados" merece especial atenção. Isso porque, embora o número de vítimas de deslocamento forçado (incluindo refugiados, solicitantes de asilo e deslocados internos) tenha aumentado drasticamente nos últimos anos e atualmente seja o maior desde a Segunda Guerra Mundial, parece que a sua utilização tornou-se mais veiculada a partir do momento em que esses migrantes passaram a adentrar no território dos chamados países "desenvolvidos", em especial, os da União Europeia. Contudo, informa dizer que essa "crise" não é europeia, muito menos brasileira, bastando analisar nos dados do ACNUR em Mid-Year Trends 2017 que informa que dentre os países que mais acolheram refugiados entre o final de 2016 e meado de 2017, somente um faz parte desse grupo de países. Nesse sentido, os países são: Turquia, Paquistão, Uganda, Líbano, Irã, Alemanha, Etiópia, Jordânia, Sudão e República Democrática do Congo, respectivamente (ALTO COMISSARIADO DAS NAÇÕES UNIDAS PARA OS REFUGIADOS. Mid-Year Trends 2017. Genebra: United Nations High

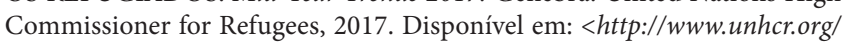
statistics/unhcrstats/5aaa4fd27/mid-year-trends-june-2017.html>. Acesso em: 09 Abr. 2018 às 19h50).
} 
year-trends-june-2017.html>. Acesso em: 09 Abr. 2018 às $19 \mathrm{~h} 50$.

Protocolo Adicional de 1967 Relativo ao Estatuto dos Refugiados. Disponível em: $<$ http://www. acnur.org/fileadmin/Documentos/portugues/BD_Legal/ Instrumentos_Internacionais/Protocolo_de_1967.pdf > . Acesso em: 03 Jul. 2018 às $18 \mathrm{~h} 32$

Refugee Protection: a guide to International Refugee Law. New York: United Nations High Commissioner for Refugees/Inter-Parliamentary Union, 2001.

BRASIL. Lei 9.474, de 22 de julho de 1997. Disponível em: $<$ http://www.planalto.gov.br/ccivil 03/Leis/L9474.htm>. Acesso em: 04 Jul. 2018 às 00h06.

BRITO, Wladimir. Direito Internacional Público, $2^{\mathrm{a}}$ Edição. Coimbra: Coimbra Editora, 2014.

CIERCO, Teresa. A instituição de asilo na União Europeia. Coimbra: Almedina, 2010.

COSTELLO, Cathryn. The Human Rights of Migrants and Refugees in European Law. Oxford, UK: Oxford University Press, 2016.

DOLINGER, Jacob. Direito Internacional Privado: parte geral, $9^{\text {a }}$ Edição. Rio de Janeiro: Renovar, 2008.

GILBERT, Geoff. Rights, Legitimate Expectations, Needs and Responsibilities: UNHCR and the New World Order. International Journal of Refugee Law. Vol. 10; pp. 350-388. Oxford: Oxford University Press, 1998.

GOODWIN-GILL, Guy S.; MCADAM, Jane. The refugee in International Law, $3^{\text {a }}$ Edição. Coleção Clarendon Paperbacks. Oxford, UK: Oxford University Press, 2007.

HATHAWAY, James C. The Law of Refugee Status. Toronto: Butterworths, 1991.

HATHAWAY, James C.; FOSTER, Michelle. The Law of Refugee Status $-2^{a}$ Edição. Cambridge, UK: Cambridge University Press, 2014.

MACHADO, Jónatas E. M. Direito Internacional: do Paradigma Clássico ao Pós-11 de Setembro, $4^{a}$ Edição. Coimbra: Coimbra Editora, 2013.

ORGANIZAÇÃO DAS NAÇÕES UNIDAS. Convention against Torture and Other Cruel, Inhuman or Degrading Treatment or Punishment. Disponível em: <http://www. ohchr.org/EN/ProfessionalInterest/Pages/CAT.aspx>. Acesso em: $26 \mathrm{Fev} .2018$ às 20h09.

ORGANIZAÇÃO DOS ESTADOS AMERICANOS. Tratado de Direito Penal Internacional de Montevidéu. Disponível em: <http://www.oas.org/es/sla/ddi/docs/ Tratado_sobre_Derecho_Penal Internacional Montevideo_1889.pdf $>$. Acesso em: 03 Jul. 2018 às $23 \mathrm{~h} 55$.

STOYANOVA, Vladislava. The principle of non-refoulement and the right of asylum-seekers to enter state territory.
Interdisciplinary Journal of Human Rights Law, v. 3, n. I, 2008. Disponível em: $<$ https://ssrn.com/abstract $=1804256>$. Acesso em: 29 Mar. 2018 às 17h14.

UNIÃO EUROPEIA. Carta de Direitos Fundamentais da União Europeia. Disponível em: $<$ http://www.europarl. europa.eu/charter/pdf/text_pt.pdf>. Acesso em: 03 Jul. 2018 às $14 \mathrm{~h} 03$.

Tratado da União Europeia. Disponível em: $\overline{<h t t p: / / p u b l i c a t i o n s . e u r o p a . e u / r e s o u r c e / c e l l a r / 9 e 8 d 52 e 1-}$ 2c70-11e6-b497-01aa75ed71a1.0019.01/DOC_2>. Acesso em: 03 Jul. 2018 às 13 h58.

Tratado sobre o Funcionamento da União Europeia. Disponível em: <https://eur-lex.europa.eu/legalcontent $/ P T / T X T /$ ? uri $=$ celex $\% 3 A 12012 E \% 2 F T X T>$. Acesso em: Acesso em: 03 Jul. 2018 às 14h01.

VIANA, Joana Azevedo. Refugiados na Hungria vão ser presos em campos de contentores nas fronteiras. Expresso, 10 Fev. 2017. Disponível em: <http://expresso.sapo.pt/ internacional/2017-02-10-Refugiados-na-Hungria-vao-serpresos-em-campos-de-contentores-nas-fronteiras $>$. Acesso em: 17 Jan. 2018 às 23 h03.

\section{JURISPRUDÊNCIA}

TRIBUNAL DE JUSTIÇA DA UNIÃO EUROPEIA. Acórdão de 02 de março de 2010, Abdulla e outros vs. Alemanha (processos C-175/08, C-176/08, C-178/08 e C-179/08), ECLI:EU:C:2010:105. Disponível em: $\quad<$ http://eur-lex.europa.eu/legal-content/EN/ $T X T / ?$ uri $=$ CELEX\%3A62008CJ0175>. Acesso em: 15 Mar. 2018 às $20 \mathrm{~h} 54$.

. Acórdão de 06 de dezembro de 2011, Alexandre Achughbabian vs. Préfet du ValdeMarne (processo C-329/11), ECLI:EU:C:2011:807. Disponível em: <http:// curia.europa.eu/juris/document/document.jsf?text $=\&$ docid $=115941 \&$ pageIndex $=0 \&$ doclang $=P T \&$ mode $=l$ st $\&$ dir $=\&$ $o c c=$ first\&part $=1 \& c i d=92391>$. Acesso em: 17 Fev. 2018 às $22 \mathrm{~h} 26$.

. Acórdão de 17 de julho de 2014, Qurbani vs. Alemanha (processo C-481/13), ECLI:EU:C:2014:2101. Disponível em: <http://curia.europa.eu/juris/document/ document.jsf?text $=\&$ docid $=155104 \&$ pageIndex $=0 \&$ doclan $g=e n \&$ mode $=1$ st\&dir $=\& o c c=$ first\&part $=1 \&$ cid $=321873>$. Acesso em: 26 Mar. 2018 às $23 \mathrm{~h} 12$.

TRIBUNAL EUROPEU DE DIREITOS HUMANOS. Acórdão de 28 de fevereiro de 2008, Saadi vs. Itália (processo originário $\mathbf{n}^{\mathbf{0}}$ 37201/06). Disponível em: $<h t t p: / /$ hudoc.echr.coe.int/eng\#\{“dmdocnumber":["829510”],"ite mid":["001-85276"]\}>. Acesso em: 14 Mar. 2018 às $21 \mathrm{~h} 15$. 